\title{
Thinking in Complexity about Learning and Education: A Programmatic View
}

\author{
TON JÖRG \\ Universiteit Utrecht (The Netherlands)
}

In this contribution the focus is on sketching a programmatic view of thinking in complexity about learning and development. This kind of thinking goes beyond linear thinking. The new thinking in complexity about a dynamic complex reality may enable us to build a new science of learning and education, which does not take the nonlinear complex reality for granted but regards it as "real": a science with a framework that does not exist yet. A new vision on learning is presented which takes the concept of interaction as a key concept, which may be linked with the notion of dynamic complexity. Thinking in complexity has its focus on "that which is interwoven". Learning and development through interaction may thus be viewed as a way of co-creating ourselves within a web of reciprocal relationships with the other. This co-creation may be described as a complex of self-generative, self-sustaining processes of mutual "bootstrapping" with potentially nonlinear effects over time. Modelling learning this way, may show learning to be a potentially nonlinear phenomenon within a new reality as the domain of possibilities and potentialities of learning. The modelling of such learning as "bootstrapping," and the concomitant effects on both partners in the interaction, shows these very possibilities and potentialities of learning in their humanly connected spaces of possibility. It demonstrates the very truth of Vygotsky's adage that "it is through others that we develop into ourselves." Based on his thoughts, we are able to develop a new view of the complex nonlinear reality of learning and education, with learners as potentially nonlinear human beings. 


\section{Introduction}

To formulate the aim of this project on learning and education, we must distinguish between the fundamental and the practical: between the foundation of a new vision about learning and the complex way learning manifests itself in the practice of education. Of course, the link between these two should be made and will be made. It is important for this project to bear in mind that "learning itself is a construction invented by mankind" (Fransella and Thomas, 1988, p. 104; emphasis added). Similarly, teaching is also an invention, as described by Brent Davis in his book Inventions of Teaching (2004). Whilst aware of these historical processes of inventing, we may open the vistas of re-inventing the field of learning and teaching. To enable such a reinvention, we need to stop thinking linearly, which is quite dangerous in a nonlinear complex reality (cf. Mainzer 2004, p. 407). We need to take the complexity of reality as reflecting the real. Only then will we be able to reinvent the science of learning and education: by overcoming the common rhetoric in use.

We should take what Giambattista Vico (1668-1744) taught us about how science operates seriously. In his writings about the science of Descartes and others at the beginning of the eighteenth century, Vico made a plea for opening our eyes and seeing how performing science with the human mind is like the operation of the eye which cannot view itself (Vico, 1744). This is similar to the mind operating with its own rhetoric. A rhetoric which seems generated by its inherent blind spots and myopia, and which demonstrates an imprisonment of meaning; an imprisonment which prevents thinking in complexity.

Like Vico, the Russian psychologist Lev Vygotsky took a critical stance when he wrote about the blind alleys of psychological science, and the crisis in psychology in his day (Vygotsky, 1997c'1 pp. 3, 13). Although he lived and worked as long ago as the first half of the twentieth century, his critical view is still relevant today. Nowadays, James Wertsch, one of the scholars studying Vygotsky, still complains about a psychological science which generates "the 'learned incapacities' and 'disciplinary pathologies' that restrict the horizons of modern academic discourse" (Wertsch, 1998, p. 11). There are a few examples of these incapacities and pathologies in the different disciplines of social science: a) the common approach of "methodological individualism", b) the common fragmentation of reality, and c) the denial of the complexity of reality of wholes by "simply" reducing them to elementary parts (cf. Vygotsky, 1997c, p. 262). Just as Vygotsky did, we may view such a restricted view on performing science as "a testimonium pauperitatis"2 (Ibid., p. 26). How can we overcome such a restriction?

It is my conviction that we need to rethink our theory and practice of learning and education. Only then can we, along with Vygotsky, become the "visitors from the future," a metaphorical description about the significance of Vygotsky and his work (in

\footnotetext{
${ }^{1}$ The complete original work of Vygotsky, written in the twenties and thirties of the last century, has only recently been translated, in collected volumes, published from 1987 (vol. 1) to 1999 (Vol. 6), with different editors.

${ }^{2}$ Declaration of poverty.
} 
Bruner, 1987, p. 7). This necessary rethinking may lead to a future full of unexpected possibilities and potentialities for learning and education. Like Bruner, we will take Vygotsky's view of development as a full theory of education (lbid., p. 1).

\section{A New View of Education}

Based on Vygotsky's ideas, a programmatic view may be outlined of how new thinking in complexity may lead to a new view of education based on new principles. The basic principle is that "learning learns itself" (Luhmann \& Schorr, 2000, p. 98): not by adapting to a context in terms of so-called "complex adaptive systems," but by the still unknown principles of creation within a complex dynamic structure where learners are linked to their environmental context, i.e. other learners. It is within such dynamic complex structures that we may think about learning and learners as "bootstrapping" each other in small (sub)communities (see Bruner, 1996, p. 21). This idea is not just a metaphor, although that is how Bruner uses it, but it can be based on the general principles of acceleration, with potentially nonlinear effects over time (see for example, Holland, 1998). We may view these nonlinear effects as a result of the potentially generative processes of linking learners to such communities; conceived as complex networks. It was Vygotsky (1997c) who already foresaw such accelerating processes of learning and development as a realistic possibility. He regarded development not as a gradual, but as a revolutionary change (p. 110; cf. Kauffman, 1995, p. 152, about catastrophic changes). The question is whether such revolutionary changes are possible in our society with its specific educational system? We know from our history of education and society at large that "It seems to be easier for society to change education than for education to change society" (Lewin, 1948, p. 4; italics in original). This history is, however, the history of linear thinking about a reduced reality of learning and education. Vygotsky's ideas on the principles of acceleration and nonlinearity may lead us in another direction. These generative principles of learning through communicative human interaction within relationships may cause education to adopt a different role in our society. The new learning envisioned, with its generative power, may ultimately take the lead in changing society. However, so far this has never happened in societal evolution (see Luhmann \& Schorr, 2000, p. 32). The science of learning and education appears to be "a testimonium pauperitatis" as well. The same holds true for the practice of education. Therefore, the rather complex question pops up: How different may education be or become? From what principles, and for what reason or purpose? Will we be able to overcome the incapacities and pathologies of our basic disciplines? These are the very problems and questions (in our sciences) whose best answers have remained unknowable (Simon, 1996). To find those answers, we have to reflect both in and on the whole system of education (see Luhmann \& Schorr, 2000). Only then will we be able to develop a new language: in Gert Biesta's words, "a language of education for education" (2006, p. 14). He argues that a new language is needed which has to be reinvented (Ibid., p. 14). By doing so, we may finally find the difference that makes the difference in our system of education. 
In summary, we should take a totally different view of education. We should put an end to an educational system which is so "geared to generate predictable citizens" (Von Foerster, 1993, p. 196), and stop "the trivialization of our children" (Ibid., p. 196). Instead, our present education may transform into the education of how to become a human being, instead of only a citizen (Luhmann \& Schorr, 2000, pp. 33-34). This new way of thinking about education is a way of making education more humanistic (cf. Vico, 1993; cf. Biesta, 2006). It is fully in line with Vygotsky's ideas and corresponds with his famous adage: "It is through others that we develop into ourselves" (Vygotsky, 1981, p. 161). Thus, in the end we may arrive at answering the question which Biesta (2006) has called "the most important question of today": "how can we respond responsibly to, and how we can live peacefully with what and with whom is other" (p. 15). This is a question whose very answer still seems to have remained unknowable (Simon, 1996). We may need a new language of education for education to answer that question.

\section{Vygotsky and Thinking in Complexity}

The aim of this contribution is to reflect the full scope of Vygotsky's thinking on its own terms (see Glick, 19973, p. viii). This is not an easy job, as Joseph Glick declares: “We must 'see through' our own habits of reading" to be able to do so (Ibid., p. vi). I fully agree with Glick that reading Vygotsky is a complex phenomenon in itself (see also Langford, 2005). It took me more than two years to become fully acquainted with the depth of his writings. It was only afterwards that I became aware that Vygotsky's way of thinking is in fact a "complexivist" way of thinking.

The essential Vygotsky may be viewed in terms of understanding developmental issues as "representing a complexly woven tapestry of functions" (Glick, 1997, p. xiii). Underlying this tapestry is a dynamic structure with its causal dynamics, which may bring forth the functions over time. Starting from the dynamic notion of the tapestry as a nonlinear complex reality, linear thinking may be shown to be dangerous (see Mainzer, 2004, p. 407; emphasis added). So we need new thinking about the nonlinear dynamics of complexity, and these dynamics are essentially causal dynamics (see Vygotsky, 1978, p. 62). This kind of thinking (in complexity) is in line with the recent thinking about the tapestry of complexity, for example by Kauffman (1995): "we are beginning to pick out themes, strands in the tapestry" (p. 185). This is very close to what complexity is really about: "that which is interwoven"4 (in Morin, 2001). But it still seems to be true that "a new conceptual framework (for the study of this kind of complexity) does not yet exist" (Kauffman, 1995, p. 185; emphasis added). In the same book Kauffman makes the rather bold statement that "Nowhere in science have we an adequate way to state and study the interleaving 5 [sic] of self-organization, selection, chance, and design" (Ibid., p. 185).

It is the aim of this contribution to develop a programmatic view and the conceptual tools needed for the study of complexity along these lines: as that which is causally, and

\footnotetext{
${ }^{3}$ Prologue in The Collected Works of L.S. Vygotsky, Vol. 4, pp. v-xvi.

${ }^{4}$ The Latin word 'complexus' means "that which is interwoven” (see Morin, 2001)

${ }^{5}$ It is not by mistake that Kauffman uses this term (rather than interweaving). He uses interleaving again at page 186:

"Stating the themes is simple. It is their interleaving that is so terribly uncertain".
} 
dynamically interwoven. We may, then, rightly ask the question: "What is the weave?" The necessary steps will be made from a trans-disciplinary perspective, for the very reason that complexity as described in this way is a trans-disciplinary concept. It is a concept about structure and emergence, for the use of explanation (Kauffman, 1995, p. 23). Using this concept of complexity may expand our notion of reality, by becoming familiar with the unknown potentialities of causal interaction within the dynamic tapestry of complexity and its inherent "explosive possibilities" (Barab \&Kirshner, 2001; cf. Kauffman, 1995, p. 28; emphasis added). Reality, then, may imply a new choice to be made about reality.

\section{The Fundamental: Reality as a Choice}

The critical stance, taken above, makes it necessary for us to be critical in our thinking and about the paradigms we commonly use in the field of learning and education. In other words: it is time to end the rhetoric about learning (see Kezar et al., 2002; and MITgroup, 2004). There is an unmistakable gap between the common science of learning and education, and the practice of education. The origin of this gap may be related to our Western, historical view of science: as a constant quest for certainty (Elkana, 2000, p. 287; cf. Bhaskar, 1991, p. 31, for philosophy). Regarding science in this way hails back to Francis Bacon's programmatic search "to penetrate and subdue nature" (Keller, 1983, p. 48). This perspective has been very successful for the natural sciences. However, it presented the social sciences with the problem of how to become a science: by becoming a science like the natural sciences, or by becoming a different kind of science? The dominant choice was becoming a copy of the natural sciences (see Schnabel, 2002, p. 223). However, the persistent question remains whether that choice also meant that the social sciences were really scientific by nature? Or may the dominant choice have been wrong? (lbid., p. 223). From a sociological point of view, Norbert Elias argued that uncertainty had been discarded by the social sciences. In his view, the resultant certainty was deceptive, for the very reason that, as he stated, "Without throwing oneself for a time into the sea of uncertainty one cannot escape the contradictions and inadequacies of a deceptive certainty" (Elias, 1991, p. 93).

This controversy about the choice to be made has also remained unresolved in the history of psychology and other social sciences (Vygotsky, 1926/1997). Therefore, it could be argued that progress has been held up as a result of insufficient concern for the epistemological foundations of scientific paradigm (PPCCS, 2001). It seems that, for this very reason, most scientists are still kinds of "prisoners of description." (Edelman \& Tononi, 2004, p. 207) It may be stated as well that we have become the captives of the blind spots and myopia of our science (Van der Veer and Valsiner, 1994). Or, to put it somewhat differently, we are still the "victims" of so-called "blinding paradigms" (Morin, 2001, p. 21). Consequently, most scholars seem to stick to description, not being able to become really explanatory about the subject of study: unable to explain "emergent behaviour" as resulting from the causal dynamics of interaction between the various components of systems. It is for these reasons that most scholars easily take 
complexity for granted (Bak, 1997). As a result, they do not seem equipped to deal with the complexity of reality (see Morin, 2001; Peschl, 2003; Elkana, 2000, p. 285). They are 'simply" disregarding essential parts, or phenomena, of reality. Most cognitive scientists seem unable to recognize and give a theoretical account of the complex, i.e. of the complexity of "real" cognition (PPCCS, 2001; Peschl, 2003). This "learned incapacity" also seems true for educational scientists with regard to not recognizing the surprising inefficiency of learning in the common practice of education (PPCCS, 2001, p. 19; emphasis added). Therefore it is time to re-think, and start thinking in complexity (Mainzer, 2004; emphasis added). We need to rethink our view of learning and education, both in theory and in practice (cf. Biesta, 2006). This effort implies the rethinking of the reality of learning and education. If educationalists can invent reality, as Davis has shown in his book about inventions of teaching (Davis, 2004), then we can re-invent reality of education too (cf. Watzlawick, 1984).

We may take up the challenge to develop a theory about the complexity of the unfolding dynamics of cognition in action with its inherent plasticity, its interactivity and generativity, and start to link such a theory with theories of learnability (PPCCS, 2001, p. 28). To start with a programmatic view, we should be critical about our basic assumptions about real learning in education. First, we should recognize the surprising inefficiency of individual learning, of learning alone, and become more aware of the generative power of learning though social interaction as a generative process, with unexpected potentialities for the partners in that interaction. Secondly, we should revise our theories and develop an integrative view of learning through interaction within personal relationships, with their concomitant possibilities in 'an enfolded domain of potentiality" (cf. Bohm, in Morgan, 1997, p. 412).

\section{A New Vision: The Conceptual Role of Interaction}

The notion of interaction is rather new in the history of our sciences (Starobinski, 2003). In the field of physics, interaction has often been described in Newtonian terms of action and reaction. The same holds true for psychology. An adequate concept of interaction has not been developed in the social sciences yet. No adequate theory of (human) interaction has so far been developed (see Mercer, 1996). It is, therefore, no surprise that Bates et al. (1999), in the Companion of Cognitive Science, put the question "what will a good theory of interaction look like when it arrives?" (p. 590)

We may be seeking a new conceptual framework that does not yet exist (cf. Kauffman, 1995, p. 185). For new thinking about learning and education we are in need of a new theory of interaction. A theory which, for our focus on learning, will be about peer-to-peer situations (P2P): i.e. face-to-face (F2F) situations in communicative human interaction (cf. Stacey, 2001, 2003). When developing such a theory, we are standing on Lev Vygotsky's shoulders. He already had his own specific view of social interaction, writing about its significance for the cognitive functioning of people who participated in such interaction. Vygotsky took the complexity of interaction seriously. He wrote for instance about the complexity of the causal dynamics of interaction (Vygotsky, 1978). He 
sketched the complex processes involved in interaction as processes mutually supporting one another in time. The potential effects, produced by those processes, were envisioned as a kind of "transformation" of processes of cognitive functioning. This transformation is the key to becoming oneself in and through interaction. The effects on each of the partners may be described as effects of reciprocal strengthening and transformation, made possible by the reciprocal influences in interaction (see Nakkula and Ravitch, 1998; Selman \& Demorest, 1986). In line with this description of interaction in terms of causal dynamics and causal influences, we may also describe such a process in terms of so-called "mind-to-mind causation" (in Bhaskar, 2002, p. 245; see also p. 15, about mind-to-mind action and interaction; and Starobinski, 2003, on interaction). Of course, the causal dynamics involved in this very process of mind-to-mind causation includes the notion of "temporal complexity", as described by Luhmann \& Schorr (2000, p. 245) These authors describe the complexity involved in this type of interaction in education as follows: "the process of seeking success requires time itself and is constantly reacting within time to itself and to the situation it has created" (Ibid., p. 245; emphases added). It is from these complex notions, in a new framework about interaction, that complex, self-reinforcing processes may be envisioned and modelled within the field of learning and education (Ibid., p. 247; cf. Holland, 1998, p. 109, about reinforcing the effects). Processes like these have also been described as "bootstrapping" processes (Van Geert, 1991; Holland, 1998). According to the dictionary ${ }^{6}$ the concept of "bootstrapping" may be described as self-generative or self-sustaining processes. These processes may be linked with the rather uncommon notion of "ongoing self-cause." (Juarrero, 1999; cf. Luhmann \& Schorr, 2000, p. 245)

Processes like bootstrapping may have potentially increasing effects over time. They show the generative power of these processes of interaction. In practice, these processes may show the potentially explosive possibilities of (causal) interaction within the field of learning and education (see Barab \&Kirshner, 2001; cf. Kauffman, 1995, p. 28). Explosive possibilities may be viewed as emergent effects of the modelling of interaction. These unexpected possibilities of interaction are effects of learning, actually already demonstrated in practice, but without any real understanding or explanation of how these could have occurred through interaction. These effects seem to be fostered through unknown generative mechanisms and unknown causal effects over time. By this, we mean the amplifier effects over time, as described by Gartner et al. (1971), and measured in practice, like the Snowball Phenomenon (Anderson et al., 2001). They may be conceived as self-reinforcing effects enabled by those causally generative bootstrapping processes; in other words, effects which may make learning unexpectedly efficient over time. We may call this kind of learning "generative learning". It is enabled through the process of "reciprocal learning" as a description of the conditions of how human interaction may take place and be organized in practice.

The key for understanding the efficiency of generative learning may be found in the so-called "states of being" of learners. These are states that have been easily disregarded

\footnotetext{
${ }^{6}$ from Dictionary.com website http://dictionary.reference.com/browse/bootstrapping (Retrieved October 16, 2007)
} 
as "bothersome internal states" in the field of learning and education (see von Foerster, 1993, p. 185). These states of learners are regarded as bothersome because they "generate unpredictability and novelty" (Ibid., p. 185; cf. Luhmann \& Schorr, 2000). But from a complexity perspective, of thinking in complexity, they show the very possibilities of human beings in their interaction. We may think of their connected spaces of evolving possibilities in human interaction.

Human beings, then, as potentially nonlinear beings, may be conceived as dynamically linked with potential states of being, complexly (inter)woven in human interaction; nonlinear beings through nonlinear processes of becoming (cf. Stanley, 2005, p. 143). This shows a way of considering human beings in their full dynamic complexity, as essentially generative in the generative kind of human connectedness (Buber, 1948, p. 87). ${ }^{7}$ They may transform each other through the unknown dynamics of complexity of their communicative human interaction (Kauffman, 1995, p. 293). This process may be viewed as a good example of emergence, of complexity as generated complexity (Holland, 1998, p. 132). The transformations of human beings and of their cognitive functioning remain unpredictable (Kauffman, 1995, p. 289). Isn't this a wonderful way of how human beings may become humanized by our thinking in complexity? Thinking along these lines confirms what Morin (2002) has put forward about the connection between complexifying and humanizing the sciences. Complexity science, may become a real innovative science (cf. Holland, 1998, p. 206). The innovative process of complexifying may show the promise of the unexpected, surprising efficiency of communicative human interaction for the field of learning and education. Education as a system may become different, by incorporating the new framework about communicative human interaction. Doing so, education may finally escape its blind focus on pre-specified ends (see Morin, 2001, p. 72; cf. Luhmann \& Schorr, 2000; and Jörg et al., 2007). We may reach the conclusion that the new system of learning and education differs strongly from common notions of (social) constructivism, as well as from the socalled notion of "instructionism" (see Langford, 2005; Edelman \& Tononi, 2000, p. 81). We may also conclude that these common notions have distorted our view of the possibilities and potentialities of learning and education.

\section{Causal Modelling of Interaction}

Above we made a connection between Vygotsky's view about the causal dynamics involved in human interaction and the possibilities and potentialities of transformation through the generative processes of "bootstrapping" which are supposedly involved in such interaction. The causal dynamics of "bootstrapping" deal with a field which is still largely unexplored. We agree with the English philosopher Roy Bhaskar that we are still unfamiliar with what he described as the hitherto unknown generative mechanisms as real part of reality (see Bhaskar, 1986; emphasis added). As a consequence, there are

\footnotetext{
${ }^{7}$ Buber is referring here to a quote in the work of Husserl (1936), who speaks about "Menschsein in generative und sozial verbundenen Menschheiten“
} 
questions whose best answers are unknown. The causal modelling of interaction may give us those answers.

The causal, generative processes of interaction reciprocally influencing one another can be modelled within the causal framework of Structural Equation Modelling (SEM). This is not very well-known in the field of modelling causal processes itself. It may actually be regarded as a kind of blind spot that such modelling is hardly used: not only as a blind spot in this field, but in the field of social sciences in general. Social scientists still seem to be "prisoners of description" in this respect, encapsulated in performing "normal science" (Kuhn, 1970). Thinking in complexity about causality may open up the possibility of what Kuhn (1970) has called "revolutionary science": a science which enables scientists to work in a different world (Ibid.). It is for a better future of education that we need to reform and revolutionize (see Luhmann \& Schorr, 2000, p. 169).

The concept of causality has always been a problem for philosophers. This is especially true for the mechanism involved in the dynamics of causality. However, it is not only true for philosophers: causal analysis of these processes in complex systems remained a hardy perennial in social science (Buckley, 1967). It is therefore no surprise that causal modelling in the social sciences is a recent phenomenon. Causal modelling was originally developed by the geneticist Sewell Wright, in the nineteen thirties. Later, in the nineteen seventies, it was picked up by Karl Jöreskog and Dag Sörbom, and developed by them into a computer program for analysis (known as LISREL, with different releases in the decades thereafter). Theorization of the dynamics of causal interaction is only developing slowly. One of the reasons is that the topic of the causal dynamics as such has not been recognized as fruitful. This is demonstrated in the books on causal models, such as the LISREL-manuals by Jöreskog and Sörbom (e.g. 1993). The vocabulary of LISREL is rather confusing as it introduces linear relationships and direct linear effects. The total effects of causal interaction, however, can turn out to be nonlinear. This important fact remains hidden in the LISREL-manuals by Jöreskog and Sörbom (e.g. 1993, in Chapter 5). Although they deal with reciprocal relationships in their modelling of causal interaction, they do not give the formulae which show the potential nonlinear total effects of such interactions within reciprocal relationships. It may be concluded that there is still an unexplored part of causal modelling of reality (cf. Long, 1987). It is about a form of causality which is not Newtonian (mechanistic), which takes no fixed entities (agents) as interacting over time.

In the last ten years I have developed a very simple causal model of the dynamics of (mutual) interaction between so-called "latent" causal variables and their timedependent effects (Jörg, 2004a, 2007). The causal dynamics of such interaction may be conceived as a self-reinforcing process of causal interaction with potential non-linear effects in time, dependent on the strength of the influences one may exert on the other. These total effects can be shown in a three-dimensional space, a "transition space" which shows the amplification of changes in the (latent) variables involved, and the potential nonlinear transitions of effects in the changes of these variables (see Holland, 1998, p. 240). The dynamics of causal interaction within dynamic reciprocal relationships is similar to the process of learners "bootstrapping" each other in a small sub-community 
(in Bruner, 1996, p. 21; see also Davis, 2004, p. 152). The concept of "bootstrapping" may be viewed as a real trans-disciplinary concept, and a new concept to be used in different disciplines like biology, economy and cognitive psychology (see e.g. Kauffman, 1995, p. 288; Koneko, 2004; Edelman, 1992, p. 119; Edelman 2004, pp. 116-117; Lotman, 1990; Holland, 1998; and Van Geert, 1991).

My model is a causal model of (mutual) interaction within a reciprocal relationship between A and B as two partners (peers) reciprocally influencing one another (cf. Selman and Demorest, 1986; Greenspan and Shankar, 2004). For that reason I have called the process of learning through interaction "reciprocal learning". The causal modelling of interaction as a process of reciprocal causation showed the potential of that interaction as a complex generative process, with unknown, unpredictable effects on each of the interacting partners. This process of the causal dynamics, and the effects of it, may be represented as a kind of spiral process of development of the people involved in that very process (Vygotsky, 1978; Bruner, 1996). So the learning may also be called "generative learning" (e.g. in Pellegrino, 1994; see also Senge, 1990, pp. 284-286, about generative learning in dyads through so-called "learningful" relationships). If the quality of interaction and the quality of relationship improves over time, the effects of such learning may become nonlinear over time. Actually, the causal modelling of the generative processes showed two fundamental laws of learning about effects of learning through interaction: the "Matthew effect", so named by the sociologist Robert Merton (1968), and the "Comenius effect" ${ }^{\prime}$, as nonlinear (causal) effects of learning over time (see Jörg, 2004a).

The reality of learning and education may become a non-linear reality; a (new) reality, of unexpected travels and adventures (cf. Bohm, 1996, p. ix); with its potential for a surprising efficiency of learning (Sternberg and Spear-Swerling, 1996, p. 119; Morin, 2001, p. 12). These effects may be described as effects of self-organization', and transformation of learning systems as time-dependent effects (Thomas and HarriAugstein, 1985; cf. Davis, 2004, p. 152, on learning systems; and Kauffman, 1995, p. 188). Learning through interaction may be conceived, as co-creating oneself as "self-creating wholes" (Kauffman, 1995, p. 274), through the cognitive and meta-cognitive activities in social interaction as an emergent social process, which is a process of transition and transformation (see also Souza-Lima, 1995, pp. 447-448). However, it is an emergent process essentially developing without a central agency, and, therefore, beyond real control (cf. Kauffman, 1995, p. 275). These characteristics turn the interaction as activity into a real adventure for the participants in that interaction (see Starobinski, 2003).

At this point, the (causally) generative processes of interaction need to be described in terms of the travels and adventures of learning to co-create ourselves, not only of oneself but of the other too. It is the complex paradigm of implication/distinction/conjunction which allows a description and explanation of the process of the learning of learning human beings in terms of causally generative

8 “Docendo didici” which means “He who teaches others, teaches himself.” In Gartner et.al., 1971, pp. 14-15.

9 Actually I prefer to speak about the concept of evolvability in co-evolution as a potential process of spiral development and about symbiosis as a potential concomitant effect, instead of self-organization. I use the last concept in order to use the same kind of trans-disciplinary language (see also Kauffman, 1995, p. 181). 
processes of bootstrapping: processes which are both inter-generative and intragenerative, or auto-generative and cross-generative in nature (Jörg, 2004b). The connection thus made, is one between cross-catalytic and autocatalytic reactions of the systems involved, and may be regarded as fundamentally trans-disciplinary (Kaneko, $2004)^{10 .}$

The generative processes of evolving selves can also be described as emergent processes; as processes of self-organization of the personal learning system in the multidimensional Vygotskian space of proximal and potential development (Moll, 2001; cf. Davis, 2004). The effects of it show the hitherto unknown generative self-reinforcing potential of learning through interaction (Bhaskar, 1976; cf. Long, 1987). The basic idea is the belief that "small changes can be used to create large effects" (Morgan, 1997, p. 415). These large effects are to be conceived as emergent, self-enhanced causal effects over time: as effects of ongoing self-cause (Juarrero, 1999). Such generative enhancement effects show us the potential for a new foundation for learning and education in our schools and universities, based on interaction within personal relationships.

Generally, good teachers (educators) have always followed this scheme, whether implicitly or explicitly. They know the importance of the difference between meaningmaking and sense-making (see Vygotsky, 1987), by taking sense-making as essential to the learning of the whole human being. The concept of sense in this dynamic sensemaking as a process may be viewed as a "complex fluid, and constantly changing process" (in Vygotsky, 1987, p. 276; cf. Hofstadter, 1995). The fluid nature and role of dynamic sense-making in the evolving of selves has been formulated as follows: "Senses infuse or influence one another such that one is contained in or modifies the other" (Vygotsky, 1987, p. 277). Meaning-making is to be taken as a necessary tool for such fluid processes of sense-making.

What needs to be done now for the field of learning and education is to make the methodological principles of the project more explicit for all teachers (educators). We need to make clear how to foster the contexts to enable the self-reinforcing "bootstrapping" effects we wish for all learners in education (Jörg, 2006; Jörg et al., 2007c).

\section{New Forms of Education Life and Adventures of New Learning and Education through Interaction}

In The Netherlands there is a great debate about forms of education and about what has been called "new learning". Schools have started to reform the way they teach their subjects and their views on how their students learn. The notion of learning and of the learner are changing as well (Davis, 2004, p. 103). Learning becomes more personal, selfregulated, self-directed, and self-organized (cf. Thomas and Harri-Augstein, 1985). This way of learning may become really efficient when the learning is autonomously

10 See also Kauffman, 1995, p. 288; and Sassone, 1996, p. 519, on the role of generativity in the process of individualization of persons; cf. also Lotman, 1990, p. 3, on the role of autocatalytic reactions; Elkana, 2001, p. 23; and Luhmann, 2002, p. 56, on the role of recursive self-reproduction in generating psychic or social systems. 
regulated and "organized" as communicative human interaction among peers: as P2P (peer-to-peer) and F2F (face-to-face). Learning becomes a personal process of co-creating meaning and sense-making within personal relationships between students, having not only direct effects on the partners in interaction, but also on the quality of their interaction and the quality of their personal relationships. In this way, learning may grow into a generative, self-reinforcing process with unexpected effects such as the Matthew and Comenius effect, mutually supporting one another in time. Therefore, it is with the help of time that such effects can manifest themselves (cf. Luhmann, 2002, p. 60). It is my strong conviction that the reality of education may become significantly different from the traditional way learning and education have been organized in our schools and universities until now. This also seems to be the intuitive notion of many school leaders in The Netherlands "experimenting" with these new forms of education and learning. However, an adequate theory of learning through social interaction, of how to make use of personal reciprocal relationships, is still lacking. Nevertheless, we know of the Snowball Phenomenon, apparent in education practice (Anderson et al., 2001; cf. Friesen et al, 2003), and of new possibilities in education: of "learners who bootstrap each other" in sub-communities of mutual learners to be created (Bruner, 1996, p. 21). It is the causal dynamics between the inter and intra-generative processes of the $m e$ and the we-experience in social interaction which makes these effects possible (cf. Vološinov, 1973, about the role of the I-experience and the we-experience; see also Greenspan et al., 2004, p. 68). Vygotsky expressed the constructive dynamics involved in his famous adage about social interaction: "It is through others that we develop into ourselves" (Vygotsky, 1981, p. 161). Thus, it is of prime importance to take the role of the other seriously for the individual person's development of higher functions: the functions of consciousness, because "the structure of the conscious, individual personality is just as social a structure as is the collective type of experience" (Vološinov, 1973, p. 89; see also Souza-Lima, 1995).

Put simply, it seems adequate to design instruction to support interaction between peers (P2P) in a F2F situation of communicative human interaction within personal relationships with their personal value orientations: relationships which have to be built as steady dyadic reciprocal relationships. Doing so, we have to overcome the common fallacies about learning and education (Sternberg and Spear-Swerling, 1996), and renew our ideas about learning and education by thinking in (dynamic) complexity about the role of interaction in learning and education. Perhaps it is along these new lines of thinking and of the "reinvention of the reality of education" (Jörg, 2004b), with a new language and a new vocabulary, that we may foster the so-called "new learning" in education (cf. Simons et al., 2000). The new reality of education will certainly be a richer reality with unexpected potentialities and possibilities within their own personal "spaces of the possible" (see Davis, 2004). 


\section{Mission in Practice}

By what means can we foster the expanding of the spaces of the possible and create an alternative reality; a reality which is based on a new generative model of a generative order (cf. Senge et al. 2000, p. 206; and Senge et al. 2004, p. 201)? A reality which, once described within a new language of a new science, may ultimately be conceived as "a language-effected reality." (cf. Davis, 2004, p. 99) What kind of language we may speak, then, for such an alternative reality of education?

Interact and interaction may be viewed as the basic elements for the new language of education; interact to be understood as "to act on one another, or as act reciprocally", and interaction as "action on each other or reciprocal action or effect." (Webster's, 1970; emphasis added)

We may talk about a new generative pedagogy based on the generative processes of interaction, where interaction is defined as communicative human interaction by partners within their learningful relationship (cf. Senge, 1990).

The focus of a new approach to learning and education will be on developing an academic course on learning and the development of learners as whole human beings, based on a radical social understanding of individuals as persons, with learning conceived as learning through F2F communicative human interaction within P2P personal relationships. Such interaction encompasses information, utterances, and (selective) understanding (Luhmann, 2002, p. 157). “Only together do they generate communication. Only together: that means, only when their selectivity can be brought to congruence." (Ibid., p. 157; emphasis added) Thus, according to Luhmann (2002), communication becomes an emergent reality, a self-generated state of affairs; one may also call it a dynamic state of structural being through a generative process of becoming (De Duve, 2002, p. 212; see also Vološinov, 1973). It is the very dynamics of sensemaking in whole human beings through meaning-making in communicative human interaction that makes learning and development inherently complex, but also promising.

The concept of learners should therefore be formulated as self-regulating, evolving learning systems, who evolve in their linking of systems by the activities of problembased and problem-posed situations, and learn in and through communicative human interaction within learning-full reciprocal relationships. Building such personal relationships is therefore a necessary precondition for the evolvability of learning (cf. Kauffman, 1995, p. 185). Based as well on the notion of self-organization, as a prerequisite for evolvability of learning (lbid., p. 188; see also fn. 7 above), and continuing within the same $\mathrm{P} 2 \mathrm{P}$ relationship, an unexplored part of a complex nonlinear reality may be opened. Doing so, the obstacles for optimal learning can be removed: not only in theory but in practice as well.

Learning through human interaction, is to be conceived as learning to know that understanding others demands awareness of human complexity (see Morin, 2001, p. 83; emphasis added). Features of such learning will be openness, (self-) criticism, and the complexity of processes and their effects, which are fully interwoven. It is possible to 
derive design principles from these ideas about the complexity of learning which may foster the learning through interaction in a generative way, with multiplier effects taking place over time. We should be aware that it is these effects that provide us with unexpected learning possibilities for our students, in our alternative reality of education. For the mission of education in practice, it means that the very possibility of generativity of learning through communicative human interaction within personal relationships can be viewed both as a state of creative being for learners to be in, and as a norm for learning and development in education (see e.g. Sassone, 1996, p. 520; cf. Luhmann \& Schorr, 2000, p. 245). This description may be viewed as valid for each of the partners in that interaction individually and for the two learners learning as a pair. Such a pair may fundamentally be described as "twosomes" (Ibid., p. 194). We may need a theory for the sociality of the twosome (Ibid., p. 194). It is along the line of thinking in complexity about the generative processes of learning through human interaction in twosomes, with temporal complexity involved in the interaction, that the statement of Luhmann \& Schorr about "learning learns itself" may be understood (Luhmann \& Schorr, 2000, p. 98). The whole idea of steering the participation in interaction as a so-called "technology problem", should be left behind (Ibid., p. 245). As a consequence, we may understand for the building of a new science of learning and education, that learning, like evolution "goes on according to principles, not systems" (lbid., p. 198; emphasis added; cf. Bhaskar, 2002, p. 271).

It may be hoped that the new answers actually open up a better future for education: an education of the unexpected, of the seemingly impossible effects of learning, based on the new notion of interaction as reciprocally influencing one another in time through causal influences (cf. Dent, 2003). Causal influences which may be viewed as "productive" causal influences (Salmon, 1993), "producing" their effects through impelling causal forces (cf. Van der Veer \& Valsiner, 1991, p. 213; Edelman, 2004; Hofstadter, 2007; and Bechtel \& Richardson, 1993, on forces operating). These forces, having their "causal potency operating in patterns" (Hofstadter, 2007), may have their causal effects within the patterns of a complex web: both of dynamically interpenetrating relationships (see Bai, 2003, p. 23) and of interpenetrating souls (Hofstadter, 2007, p. 270). It is through weaving the web that human beings may become nonlinear beings, becoming nonlinearly productive through interpenetrating, nonlinear effects over time (cf. Bai, 2003).

Based on this new paradigm and new science of learning, a new complex, interactive, and generative pedagogy can be built (see Jörg, 2006; cf. Senge et al., 2000, p. 206) which should simultaneously be considered as an essentially transformative pedagogy (Senge et al., 2000, p. 210). This new pedagogy, which is supposed to be an essentially effective pedagogy (Ibid., p. 206), should bring with it the new language of learning and education needed for this field; a radical new language, consisting of what David Jardine described as "swarming ideas of interconnectedness, interdependency, interpenetration, recursiveness, and dependent coorigination" (Jardine et al., 2006, p. 93). Using this new language may not only be a way of breaking away from old ideas and habits of thought, creating a new reality, but also a way of decoding reality (see 
Pinar, 2006, in Jardine et al., 2006, p. x), a way of escaping the language force that creates realities by their speakers (Pinker, 1989, p. 1; cf. Davis, 2004, pp. 99, 140). It may not only become a way of revolting against the simplicity of reality in educational science, but also open up a vista of a re-enchantment of reality, of a re-enchanted world (Bhaskar, 2002, pp. 242-243).

The new language, will describe a new reality: about causal connectivity, causal interactivity, and causal generativity as the basic concepts enabling both the qualitative description and the full understanding and causal explanation of learning, learnability, and evolvability as complex processes of dynamic interweaving and their dynamic, potentially nonlinear effects. This will be a language which fundamentally goes beyond the locus of the individual (Davis, 2004, p. 105; cf. Stacey, 2003, on the radically social understanding of individuals). We may, then, also talk about causally generative bootstrapping processes and their effects over time as explosive possibilities of learning through change (Barab and Kirshner, 2001; see also Odling-Smee et al., 2003, pp. 316317, for evolutionary explosive effects of population size). These are effects of learning, actually already demonstrated in practice, but lacking a real understanding or explanation of how they could have occurred; effects which seem to be fostered through unknown generative mechanisms and unknown causal effects over time. We mean nonlinear effects like the Snowball Phenomenon (Anderson et al., 2001), and the Matthew and Comenius effect. They may be conceived as self-reinforcing effects made possible by those causally generative bootstrapping processes (see Jörg, 2005, 2006), which make learning a real human affair, based on notions of relational dynamics, as well as changing strengths of relationships, reciprocity and reciprocal attunement in human interaction. The human being, becomes a nonlinear being, complexly (inter)woven, being nonlinear through nonlinear processes of becoming (cf. Stanley, 2005, p. 143).

Learning becomes a process of co-creating each other in progressive experience, which fully depends on the relationship between the learners (Follett, 1924, p. 54), through processes of shared meaning-making and personal sense-making in and over time. A new language is urgently needed to describe these experiences and their effects as fundamentally, causally generative in nature.

\section{Conclusions}

In this contribution the focus has been on thinking in complexity, in terms of "that which is interwoven." A programmatic view has been outlined about how to think in complexity about a new, nonlinear complex reality: the complex reality of learning through interaction. A view which is needed to build a new framework for science: a framework that does not yet exist; a framework that cannot "simply" be found, but has yet to be invented.

The basic idea of this contribution to theorizing on learning and education, with their unexpected potentialities, is not only to describe these unexpected potentialities of learning within learners, with learners conceived as "transitory learners" (Vygotsky, 
1987, p. 91, based on Goethe's concept of the "transitory child"). On the contrary: the focus is really to understand and explain the manifestation of those potentialities as emergent reality. We may speak, with Mainzer (2004), about a new, nonlinear, complex reality which "is shaped by generative mechanisms in the domain of the real" (Morgan, 1997, p. 413; emphasis added). Reality, then, may be understood differently: as possibilities and potentialities, co-emerging in relationships through dynamic nonlinear processes of causation within and between whole human beings in (their) complex tapestry of functions and relationships. It is through conceptualizing the role of networks as so-called "augmented transition networks" (Hofstadter, 1987), and their modes of interaction that such understanding and explaining may become possible. Based on this notion, reality of learning and education may become really different.

Learning in interaction by whole human beings should be viewed as dynamic processes of change both within and between dynamically interconnected networks of whole human beings. The phenomena of learning may be viewed as "emergent" phenomena in interconnected networks (see Bechtel \& Richardson, 1993, p. 202). These may be explained as dynamically dependent both on the activities of the components within whole human beings and on the modes of interaction (Ibid., p. 202). These modes of interaction as dynamic, causally generative processes may be considered as nonlinear with their corresponding nonlinear effects, manifesting themselves as "the engine" of the "emergent effects" on the inherently complex functioning of whole human beings.

It is through the activities and progressive experiences of whole human beings in human communicative interaction, taking place within and through their dynamic reciprocal relationships, that the "emergent" phenomena may become apparent over time as effects of self-generated, self-reinforcing, self-sustaining causal processes. We mean phenomena like the Snowball Phenomenon, and the Matthew and Comenius Effect, as real expressions of the dynamics of "explosive possibilities" (Barab and Kirshner, 2001).

The reality of learning and education, becomes a new reality: a "reality" as a domain of possibilities and potentialities. A domain to be conceived as shaped, or to be created as the effect of never-ending causal chains of causal interaction, linked with chains of causal events (Vygotsky, 1997b, p. 9; cf. Kennedy, 2002, p. 37; see also Bohm, in Morgan, 1997, p. 413; and Bhaskar, 1989). It is for this reason that we fully agree with Vygotsky that it is "not things or reality that push the children's mind along the path of development. Reality is itself processed and transformed by the mind" (Vygotsky, 1987, pp. 87-88; emphasis added). This new notion of reality is fully in line with that of Bohm (1996). All of this thinking means a fundamental reversal of "the usual relationship between reality and change" (Morgan, 1997, p. 412). It may be regarded as an invitation for an ambitious scientific enterprise in the field of learning and education: "to discover "the laws of the whole", which embrace the processes that produce the explicate world" (Ibid., p. 412).

If all of the steps mentioned above can be made successfully, we may "really" decode the reality of learning and education by focussing on a new language (see Pinar, 
2006, p. x). These steps show the power of "language that creates as it decodes reality" (Ibid., p. x), a language that may create a new reality as a domain of possibilities and potentialities. This new reality, which may, then, be regarded as a domain of "languageeffected realities" (Davis, 2004, p. 99).

Our new thinking in complexity about a nonlinear complex reality may ultimately enable us to rewrite the code by "inventing" a new language for that new reality, which is fully based on human communicative interaction within dynamic relationships. Doing so, we may open up a vista for a new science of learning and education, which shows the dynamic generativity of learning as a process of "bootstrapping" enabled through hitherto unknown, causally generative mechanisms, with their "explosive possibilities" and potentialities of learning. Dynamic generativity is to be taken both as a state of being of learners learning, and as a norm for such learning in human interaction. It is the very generativity of the state of being of learners which is also responsible for the individualization of learners as whole human beings. For the modelling of the dynamic generativity, created through generative mechanisms in "bootstrapping" processes, we may use the still unexplored tool of causal modelling of nonlinear processes over time. This tool may be regarded as the foundation stone for the new science of learning through interaction: the stone that has been disdained for so long (cf. Vygotsky, 1987, p. 91).

The dynamic complexity paradigm of thinking in complexity about reality of learning and education, and the corresponding causal modelling of this dynamic complexity will enable us to overcome the myths we live by in the field of learning and education (Midgley, 2001, 2004; Morin, 2001; Wolf, 2002) and which are the result of the blind spots of mainstream thinking: the myths which may lead to what Edgar Morin has called a "perverted system of education", with its blind focus on ends (see Morin, 2001, p. 72; cf. Davis, 2004, p. 183; and Jörg et al., 2007c).

The programmatic view for a new science of learning and education will be of a framework that does not yet exist. It will be an innovative science, based on new thinking in complexity (Jörg et al., 2007c; Jörg, 2009). This new way of thinking will provide the possibility to escape the danger of linear thinking in a nonlinear complex reality (Mainzer, 2004). This complex reality may already be, or will become, the very reality of learning and education: a domain of possibilities and potentialities. Ultimately, this new science may provide the answers to some of the questions which only seemed unknowable for such a long time.

\section{Acknowledgements}

I would like to thank the different reviewers with their critical and helpful comments on an earlier version of this contribution. 


\section{References}

Anderson, R.C., K. Nguyen-Jahiel, B. McNurlen, A. Archodidou, K. So-young, A. Reznitskaya, M. Tillmanns, and L. Gilbert. 2001. "The Snowball Phenomenon: Spread of ways of talking and ways of thinking across groups of children." Cognition and instruction 19, no. 1: 1-46.

Azmitia, M. 1996. "Peer interactive minds: developmental, theoretical, and methodological issues." In Interactive minds. Life-span perspectives on the social foundation of cognition, edited by P. Baltes and U. M. Staudinger, 133-162. Cambridge MA: Cambridge University Press.

Bai, H. 2003. "On the edge of chaos: Complexity and ethics." In Proceedings of the 2004 Complexity science and educational research conference, 19-30, Sep 30-Oct 3 Chaffey's Locks, Canada, 2003. http://www.complexityandeducation.ca

Bak, P. 1997. How nature works. The science of self-organized criticality. Oxford: Oxford University Press.

Barab, S. A. and D. Kirshner. 2001.“Guest Editors' introduction: Rethinking methodology in the learning sciences." Journal of the learning sciences 10, no. 1\&2: 5-15.

Bates, E., J. L. Elman, M. H. Johnson, A. Karmiloff-Smith, and K. Plunkett. 1998. "Innateness and emergentism." In A companion to cognitive science, edited by W. Bechtel, and G. Graham, 590-601. Malden MA: Blackwell Publishers.

Bechtel, W. and R.C. Richardson. 1993. Discovering complexity. Princeton NJ: Princeton University Press.

Bhaskar, R. 1986. A realist theory of science. London: Verso.

Bhaskar, R. 1989. Reclaiming reality. London: Verso.

Bhaskar, R. 1991. Philosophy and the idea of freedom. Oxford: Blackwell.

Bhaskar, R. 2002. Reflections on meta-reality. Transcendence, emancipation and everyday life. New Delhi: Sage Publications.

Biesta, G. 2006. Beyond Learning. Democratic Education for a Human Future. Boulder: Paradigm Publishers.

Bohm, D. 1996. On creativity. London: Routledge.

Bruner, J. 1987. "Prologue to the English edition." In The collected works of L. S. Vygotsky, Vol. 1. Problems of general psychology, edited by R.W. Rieber and A.S. Carton, 1-16. New York: Plenum Press.

Bruner, J. 1996. The culture of education. Cambridge MA: Harvard University Press.

Buber, M. 1948. Das problem des Menschen. Heidelberg: Verlag Lambert Schneider.

Buckley, W. 1967. Sociology and modern systems theory. Englewoods Cliffs NJ: Prentice-Hall.

Davis, B., D. Sumara, and R. Luce-Kapler. 2000. Engaging minds. Learning and teaching in a complex world. Mahwah: Lawrence Erlbaum Ass.

Davis, B. 2004. Inventions of teaching. A genealogy. Mahwah: Lawrence Erlbaum Ass.

De Duve, Chr. 2002. Life evolving. Molecules, mind, and meaning. Oxford: Oxford University Press.

Dent, E. 2003. "The interactional model: An alternative to the direct cause and effect construct for mutually causal organizational phenomena." Foundations of science, 8: 295-314.

Eco, U. 1984. Semiotics and the philosophy of language. London: The MacMillan Press.

Edelman, G. and G. Tononi. 2000. Consciousness. How matter becomes imagination. London: Penguin Books.

Edelman, G. 2004. Wider than the sky. A revolutionary view of consciousness. London: Penguin Books.

Elias, N. 1991. The society of individuals. New York: Continuum.

Elkana, Y. 2000. "Rethinking - not unthinking - the Enlightenment." In Debates on issues of our common future, edited by W. Krull. Weilerswist: Velbruck Wissenschaft.

Also via http://www.ceu.hu/yehuda rethinking enlightnment.pdf.

Epstein, J. M. 2006. Generative social science: Studies in agent-based computational modelling. Princeton: Princeton University Press.

Follett, M. P. 1924. The creative experience. New York: Longmans. 
Also (partly available) via http://www.follettfoundation.org/writings.htm.

Fransella, F. and L. Thomas. 1988. Experimenting with personal construct psychology. London: Routledge and Kegan-Paul.

Frawley, W. 1997. Vygotsky and cognitive science. Language and the unification of the social and computational mind. Cambridge MA: Harvard University Press.

Friesen, Sh., P. Clifford, and D. Jardine. 2003. .. "Jenny's Shapes." Philosophy of mathematics education journal, 17 (2003), http://www.people.ex.ac.uk/PErnest/pome17/jenny.htm

Gartner, A., M. C. Kohl, and F. Riessman. 1971. Children teach children. Learning by teaching. New York: Harper and Row Publishers.

Greenspan, S. I. and S. G. Shanker. 2004. How symbols, language, and intelligence evolved from our primate ancestors to modern humans. Cambridge, MA: Da Capo Press.

Hofstadter, D. 1979. Gödel, Escher, Bach. New York: Basic books.

Hofstadter, D. 1995. Fluid concepts and creative analogies. New York: Basic books.

Hofstadter, D. 2007. I am a strange loop. New York: Basic books.

Holland, J. 1998. Emergence. From chaos to order. Cambridge MA: Perseus Books.

Jardine, D. W., S. Friesen, and P. Clifford. 2006. Curriculum in abundance. Mahwah NJ: Lawrence Erlbaum Ass.

Jöreskog, K.G. \& D. Sörbom. 1993. LISREL8: A Guide to the Program and Applications. Chicago: SPSS.

Jörg, T. 2004a. "A theory of reciprocal learning in dyads." Cognitive systems 6, no. 2, 3 (2004a): 159-170. European Society for the Study of Cognitive Systems (ESSCS), Groningen (The Netherlands): ESSCS.

Jörg, T. 2004b. "Complexity theory and the reinvention of reality of education." In Proceedings of the Complexity Science and Educational Research Conference, 121-146, 30 September-3 October 2004, at Chaffey's Locks, Canada. http://www.complexityandeducation.ca

Jörg, T. 2005. "A generative complexity theory of minds evolving in peer interaction" [Abstract]. In Towards a science of complex systems. ECCS' Proceedings of the European Complex Systems Society. Abstracts Book, edited by P. Bourgine, F. Képès, and M. Schoenauer, 210. Paris: European Complex Systems Society.

Jörg, T. 2006. "Towards a new learning science for the reinvention of education - A trans-disciplinary perspective." In Educational research, policy and practice in an era of globalization. Abstract Book. 92. Hong Kong: The Asia-Pacific Educational Research Association.

Jörg, T. 2007a. "Holistic education and complexity thinking." In The world of educational quality, edited by E. L. Baker \& D. M. Koretz. 225. Chicago: American Educational Research Association.

Jörg, T. 2007b. "Rethinking the learning organization." Paper presented at the Complexity, Science \& Society Conference, 11-14 September 2005, in Liverpool, United Kingdom. http://www.knowledgeboard.com/lib/3438

Jörg, T., B. Davis, and G. Nickmans. 2007b “Towards a new, complexity science of learning and education"Educational Research Review 2, no. 2, 145-156.

Jörg, T. 2009 New thinking in complexity for the social sciences. A trans-disciplinary approach (book, in preparation). New York: Springer Publishers.

Juarrero A. 1999. Dynamics in action. Intentional behaviour as a complex system. Cambridge MA: MIT Press.

Kauffman, S. 1995. At home in the universe. New York: Oxford University Press.

Kennedy, D. F. 2000. Rethinking reality. Ann Arbor: University of Michigan Press.

Kezar, A., D. J. Hirsch, and C. Burack. 2002. "Understanding the role of academic and student affairs collaboration in creating successful learning environment." New directions for higher education, no. 116 (Winter). San Francisco: Jossey-Bass.

Koneko, K. 2004. Life as a complex system. Presentation at the first European conference on complex systems, 5-7 December 2004, Torino, Italy. 
Korthagen, F. 2001. Linking practice and theory. The pedagogy of realistic teacher education. Mahwah: Lawrence Erlbaum Ass.

Kuhn, T. S. 1970. The structure of scientific revolutions (2nd ed.). Chicago: Chicago University Press.

Kuhn, A. 1966. The study of society: a multidisciplinary approach. London: Tavistock.

Langford, P. E. 2005. Vygotsky's developmental and educational psychology. Hove: Psychology Press.

Lewin, K. 1948. Resolving social conflicts. Selected papers on group dynamics. New York: Harper \& Row and John Weatherhill.

Long, J. S. 1987. "Problems and prospects for research on sex differences in the scientific career." In Women: Their under-representation and career differentials in science and engineering. Proceedings of a workshop, edited by L. S. Dix, 157-169. Washington: National Academy Press.

Lotman, Y. M. 1990. Universe of the mind. A semiotic theory of culture. Bloomington: Indiana University Press.

Luhmann, N. 2002. Theories of distinction. Stanford: Stanford University Press.

Luhmann, N. 2003. "The cognitive program of constructivism and a reality that remains unknown." In From modernism to postmodernism: An anthology, edited by L. E. Cahoone (2nd ed.), 496-511. London: Blackwell Publishing Ltd.

Luhmann, N. \& K-E. Schorr. 2000. Problems of reflection in the system of education. European Studies in Education, Vol. 13. Münster: Waxmann.

Mainzer, K. 2004. Thinking in complexity. The computational dynamics of matter, mind, and mankind. Berlin: Springer.

Maruyama, M. 1992. "Interrelations among science, politics, aesthetics, business management, and economics." In Context and complexity. Cultivating contextual understanding, edited by $\mathrm{M}$. Maruyama, 1-34. New York: Springer.

Merton, R. K. 1968. “The Matthew Effect in science.” Science 159, 156-163.

Midgley, M. 2001. Science and poetry. London: Routledge.

Midgley, M. 2004. The myths we live by. London: Routledge.

MIT-group. 2004. "Mission statement." http://learning.media.mit.edu/mid mission.html

Moll, L.C. 2001. "Through the mediation of others: Vygotskian research on teaching." In Handbook of Research on Teaching (4th ed.), edited by V. Richardson, 111-129). Washington DC: AERA.

Morgan, G. 1997. Images of organization. Thousands Oaks: Sage.

Morin, E. 2001. Seven complex lessons in education for the future. Paris: UNESCO Publishing.

Nakkula, M. J. \& S. M. Ravitch. 1998. Matters of interpretation. Reciprocal transformation in therapeutic and developmental relationships. San Francisco: Jossey-Bass.

Odling-Smee, F.J., K.N. Laland, and M.W. Feldman. 2003. Niche construction. The neglected process in evolution. Princeton: Princeton University Press.

Pellegrino, J. W. 1994. "Generative learning and anchored instruction: design, research and implementation issues." In New directions in educational research, edited by B. P. M. Creemers and G. J. Reezigt, 33-61. Groningen: ICO-publications.

Peschel, M.F. 2003... Philosophy matters - On the role of philosophical concepts in cognitive science. Cognitive systems 6, no. 1, 11-29. European Society for the Study of Cognitive Systems (ESSCS), Groningen (The Netherlands): ESSCS.

Pinar, W.F. 2006. "The lure that pulls flowerheads to face the sun." In Curriculum in abundance, edited by D. Jardine, S. Friesen, and P. Clifford, ix-xxii. Mahwah NJ: Lawrence Erlbaum.

Pinker, S. 1989. Learnability and cognition. Cambridge MA: The MIT Press.

PPCCS (Program Preparation Committee for the Cognitive Sciences). 2001. Fruits of enlightenment. A special program for the cognitive sciences. Report of the NWO Program Preparation Committee for the Cognitive Sciences. The Hague: Netherlands Organization for Scientific Research (NWO).

Salmon, W. C. 1993. “Causality: Production and propagation.” In Causation, edited by E. Sosa and M. Tooley, 154-171. Oxford: Oxford University Press. 
Sassone, L.A. 1996. "Philosophy across the curriculum: A democratic Nietzschean pedagogy." Educational theory 46, no. 4, 511-524.

Schnabel, P. 2002. "Science and Democracy: A difficult relationship." In The future of the sciences and humanities, edited by P. Tindemans, A. Verrijn-Stuart, and R. Visser, 212-225. Amsterdam: Amsterdam University Press.

Senge, P. 1990. The fifth discipline. The art and practice of the learning organization. New York: Doubleday.

Senge, P., T. Cambron-McCabe, B. Smith, J. Dutton and A. Kleiner. 2000. Schools that learn. New York: Doubleday.

Senge, P., C. O. Scharmer, J. Jaworski, and B. S. Flowers. 2004. Presence. Exploring profound change in people, organizations and society. London: Nicholas Brealey Publishing.

Simon, H. A. 1996. The sciences of the artificial. Cambridge MA: MIT Press.

Simons, R-J., J. van der Linden, and T. Duffy. 2000. New learning. Dordrecht: Kluwer Academic Publishers.

Souza-Lima, E. 1995. "Culture revisited: Vygotsky's ideas in Brazil." Anthropology and education quarterly 26, 443-457.

Stacey, R. D. 2001. Complex responsive processes in organizations. London: Routledge.

Stacey, R. D. 2003. Complexity and group processes. A radically social understanding of individuals. Hove: Brunner-Routledge.

Stanley, D. 2005. "Paradigmatic complexity. Emerging ideas and historical views of the complexity sciences." In W (eds.), Chaos, Complexity, Curriculum, and Culture, edited by W. E. Doll Jr, M. J. Fleener, D. Trueit, and J. St. Julien, 133-151. New York: Peter Lang.

Starobinski, J. 2003. Action and reaction. The life and adventures of a couple. New York: Zone books.

Sternberg, R. J. and L. Spear-Swerling. 1996. Teaching for thinking. Washington: APA.

Thomas, L. F. and E. S. Harri-Augstein. 1985. Self-organised learning. Foundations of a conversational science for psychology. London: Routledge and Kegan Paul.

Van der Veer, R. and J. Valsiner. 1991. Understanding Vygotsky. London: Blackwell Publishers.

Van der Veer, R. and J. Valsiner,(eds. 1994..) The Vygotsky reader. London: Blackwell Publishers.

Van Geert, P. 1991. "A dynamic systems model of cognitive and language growth." Psychological review 98, 3-53.

Verene, D. Ph. 1993. "Introduction: On Humanistic Education." In G. Vico, On humanistic education, 130. Ithaca: Cornell University Press.

Vico, G. 1744/1993. The new science of Giambattista Vico. Ithaca: Cornell University Press.

Vico, G. 1993. On humanistic education. Ithaca: Cornell University Press.

Vološinov, V.N. 1930/1973. Marxism and the philosophy of language. New York: Seminar Press.

Von Foerster. H. 1993. Understanding understanding. New York: Springer-Verlag.

Vygotsky, L. 1978. Mind in society. Cambridge MA: Harvard University Press.

Vygotsky, L. 1987. Collected works, Vol. 1. Problems of general psychology. edited by R.W. Rieber, and A.S. Carton. New York: Plenum Press.

Vygotsky, L. 1997a. Collected works, Vol. 3. Problems of the theory and history of psychology, edited by R.W. Rieber, and J. Wollock. New York: Plenum Press.

Vygotsky, L. 1997b. Educational psychology. Boca Raton: St Lucie Press.

Vygotsky, L. 1997c. Collected works, Vol. 4. The history of the development of higher mental function, edited by R. W. Rieber. New York: Plenum Press.

Watzlawick, P. (ed. 1984..) The invented reality. How do we know what we believe we know? Contributions to constructivism. New York: W.W. Norton and Company.

Wolf, A. 2002. Does education matter?Myths about education and economic growth. London: Penguin Books. 


\begin{abstract}
About the Author
Ton Jörg has been involved in complex systems and complexity thinking since 1971 and has been an educational scientist at the University of Utrecht since 1982. He obtained a BSc in Physics and Mathematics from the University of Amsterdam in 1970, an M.A in Psychology from the same university in 1977, and completed his dissertation about the choice of physics as an examination subject in 1994. He has worked as an evaluation researcher in different national and international projects and is currently writing a book about "New Thinking in Complexity for the Social Sciences. A Trans-Disciplinary Approach." He may be contacted at the following email address: A.G.D.Jorg@uu.nl; agdjorg@gmail.com.Website:http://www.ivlos.uu.nl/deorganisatie/wiewatwaar/medewerkers/jrg/7000 main.html
\end{abstract}

(C) Copyright 2009. The author, TON JÖRG, assigns to the University of Alberta and other educational and non-profit institutions a non-exclusive license to use this document for personal use and in courses of instruction provided that the article is used in full and this copyright statement is reproduced. The author also grants a non-exclusive license to the University of Alberta to publish this document in full on the World Wide Web, and for the document to be published on mirrors on the World Wide Web. Any other usage is prohibited without the express permission of the authors. 